Jurnal Keperawatan Silampari

Volume 3, Nomor 2, Juni 2020

e-ISSN: 2581-1975

p-ISSN: 2597-7482

DOI: https://doi.org/10.31539/jks.v3i2.1052

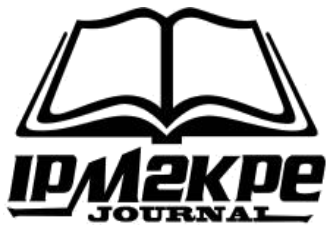

\title{
PERKEMBANGAN MOTORIK HALUS ANAK USIA PRA SEKOLAH 4-5 TAHUN DENGAN KEGIATAN MONTASE
}

\author{
I Made Sundayana ${ }^{1}$, Kadek Yudi Aryawan ${ }^{2}$, Putu Cyndy Fransisca ${ }^{3}$, \\ Ni Made Dwi Yunica Astriani ${ }^{4}$ \\ Sekolah Tinggi Ilmu Kesehatan Buleleng 1,2,3,4 \\ madesundayana@gmail.com ${ }^{1}$
}

\begin{abstract}
ABSTRAK
Tujuan dari penelitian ini yaitu untuk menganalisis pengaruh kegiatan montase terhadap perkembangan motorik halus anak usia pra sekolah 4-5 Tahun. Metode penelitian yang digunakan adalah pra eksperimental dengan rancangan one group pre and post test design. Hasil penelitian didapatkan nilai rata-rata pre test adalah 43,44 dan nilai ratarata post test adalah 68,21 . Hasil uji paired sample T-test didapatkan hasil $\rho$-value $(0,000)<\alpha(0,05)$, ada pengaruh kegiatan montase terhadap perkembangan motorik halus anak usia pra sekolah 4-5 tahun. Simpulan, motorik halus merupakan gerakan terbatas dari bagian yang meliputi otot-otot kecil terutama gerakan dibagian jari-jari tangan contohnya yaitu menulis, menggambar, dan memegang sesuatu.
\end{abstract}

Kata Kunci : Anak Usia 4-5 Tahun, Kegiatan Montase, Perkembangan Motorik Halus

\begin{abstract}
ABSTARCT
The purpose of this study is to analyze the effect of montage activities on the fine motor development of pre-school aged children 4-5 years. The research method used was preexperimental with one group pre and post test design. The results showed an average pre-test value was 43.44 and the post-test mean value was 68.21. Paired Sample T-test results obtained $\rho$-value $(0,000)<\alpha(0.05)$, there is the effect of montage activity on fine motor development in pre-school age children 4-5 years. Conclusion, fine motor is a limited movement of parts that include small muscles, especially movements of the fingers such as writing, drawing, and holding something.
\end{abstract}

Keywords: Children 4-5 Years Old, Montage Activities, Fine Motor Development

\section{PENDAHULUAN}

Penelitian yang dilakukan oleh Padila et al, (2019) selama 1 bulan pada anak usia toddler didapatkan hasil tidak terdapat perbedaan yang signifikan antara kedua metode pengukuran. Metode DDST digunakan untuk menilai perkembangan anak sedangkan SDIDTK untuk menilai pertumbuhan dan perkembangan anak. Anak usia pra sekolah merupakan anak yang berusia antara 0-6 tahun. Anak pra sekolah usia 4-6 tahun dianggap sebagai usia keemasan karena pada saat usia tersebut anak sedang mengalami pertumbuhan dan perkembangan yang sangat cepat baik secara fisik maupun psikis.

Penilaian perkembangan anak dilihat dari keaktifan anak dalam melalukan sesuatu. Penelitian yang dilakukan oleh Susilawati (2019) menunjukkan bahwa penilaian kecerdasan anak usia dini dalam aspek bekerja sama, bersosialisasi dan 
menghargai temannya dalam bekerja dapat ditingkatkan dengan menggunakan metode pemberian tugas kelompok.

Dari data WHO (World Health Organitation) melaporkan bahwa 5-25\% dari anak-anak usia pra sekolah menderita disfungsi otak minor termasuk gangguan perkembangan motorik halus. Dari data UNICEF (United Nations Children's Fund) anak usia balita yang mengalami gangguan motorik halus dan motorik kasar adalah sebanyak 1.375 .000 per 5 juta keterlambatan perkembangan.

Penelitian oleh Alif (2019) dengan tehnik observasi pada 21 anak usia 5-6 tahun dofokuskan pada 7 aktivitas motorik halus yaitu: menganyam, mewarnai gambar sederhana, membuat gambar dengan kolase, menggunting, menirukan lipatan kertas sederhana, melukis dengan jari, dan menirukan garis didapatkan hasil sebagian besar anak berada pada kategori belum berkembang. Sehingga perlu di berikan strategi penggunaan variasi media yang dapat meningkatkan motorik halus pada anak.

Penelitian oleh Irma (2018) pada 14 anak usia 4-5 tahun dengan metode observasi. Penggunaan metode demonstrasi cocok untuk kegiatan yang meminta anak-anak menirukan apa yang dilakukan guru. Penggunaan alat peraga dapat menstimulasi anak menjadi antusias, senang dan tidak mudah menyerah. Metode demonstrasi pada kegiatan 3M dapat meningkatkan perkembangan motorik halus pada anak.

Perkembangan motorik halus merupakan koordinasi halus pada otot-otot kecil yang memainkan suatu peran utama. Penelitian yang dilakukan oleh Rakimahwati et al, (2018) dengan jenis penelitian quasi eksperimen terhadap 24 anak usia 5-6 tahun. Karigami terbukti dapat meningkatkan kemampuan motorik halus anak usia dini.

Penelitian oleh Intan (2018) menggunakan metode quasi eksperimen dengan 50 siswa usia 4-6 tahun dengan metode observasi dan test. Tehnik mozaik dapat meningkatkan kemampuan motorik halus pada anak. Tehnik mozaik dapat merangsang jari dan pergelangan tangan anak untuk bergerak, anak mampu mengkoordinasikan mata dan tangan untuk fokus. Penelitian oleh Maghfuroh (2018) pada 44 anak usia 3-6 tahun dengan menggunakan DDST selama 1 bulan setiap minggu dua kali selama 15 menit. Setelah diberikan bermain puzzle perkembagan anak usia pra sekolah normal $(88,4 \%)$. Metode bermain puzzle dapat melatih koordinasi otot-otot kecil pada tangan untuk memengang dan meletakkan potongan gambar sehingga meningkatkan motorik halus.

Salah satu upaya yang dapat dilakukan untuk meningkatkan perkembangan motorik halus anak melalui metode bermain seperti kegiatan montase. Karya montase dihasilkan dari menyatukan dan menggabungkan gambar dari berbagai sumber yang berbeda-beda dengan susunan tertentu yang ditempelkan pada sebuah bidang datar. Dalam kegiatan montase terdapat unsur menggunting dan menempel yang menuntut gerakan otot jari-jari tangan koordinasi pada mata dan tangan serta daya imajinatif dalam menghasilkan sebuah karya yang dapat menstimulasi perkembangan motorik halus. Penelitian yang dilakukan oleh Titi (2018) pada 10 anak usia 5-7 tahun menggunakan metode action research. Desain penelitian dengan model Kemmis dan Taggart yaitu dikakukan dalam tiga siklus dan tiga tindakan pada setiap siklusnya. Kegiatan montase dapat meningkatkan kreativitas anak dan memberikan kebebasan anak untuk bereksplorasi, bebas menggunting, membuat dan memilih sendiri gambar yang menarik untuk disusun sesuai keinginan.

Penelitian yang dilakukan oleh Cahyaningrum (2019) dengan sampel dalam penelitian ini 15 anak dengan model penelitian McTaggart dengan tehnik pengumpulan data menggunakan lembar observasi bentuk checklist. Kegiatan montase dapat meningkatkan keretampilan motorik halus $81,52 \%$. 
Berdasarkan studi pendahuluan yang dilakukan pada di TK Saiwa Dharma dengan jumlah keseluruhan siswa yang berusia 4-5 tahun adalah 53 orang anak. Dengan menggunakan lembar observasi denver II terhadap 10 orang anak $(18,9 \%)$ secara acak dengan rentang usia 4-5 tahun didapatkan hasil bahwa 4 orang anak (4\%) dikategorikan normal, 4 orang anak (4\%) dikagorikan caution, dan 2 orang anak (2\%) dikategorikan delayed.

Penggunaan metode montase untuk meningkatkan motorik halus pada anak pra sekolah dilakukan pada beberapa penelitian. Namun, penelitian ini lebih menekankan pada efektifitas metode montase dengan menggunakan pendekatan denver II. Sehingga dapat dianalisis lebih mendalam tentang perkembangan motorik halus pada anak prasekolah.

\section{METODE PENELITIAN}

Penelitian ini merupakan penelitian kuantitatif yang menggunakan desain penelitian pra-eksperimental dengan rancangan one group pre and post test design. Sampel pada penelitian ini adalah 39 orang anak usia 4-5 tahun. Tahap pertama memilih responden sesuai kriteria inklusi dan eksklusi, kedua memberikan informasi kepada responden kegiatan montase dengan jelas, ketiga meminta persetujuan pasien untuk menjadi responden, keempat melakukan kontrak waktu dengan responden dan guru terkait pelaksanaan, kelima melakukan pre test perkembangan motorik halus, keenam melakukan Kegiatan montase dilakukan 3 minggu dan diterapkan 2 kali dalam seminggu pada anak, ketujuh melakukan post test perkembangan motorik halus lembar observasi DDST. Kaji etik dalam penelitian ini dilakukan oleh Komite Etik Penelitian Kesehatan (KEPK) Sekolah Tinggi Ilmu Kesehatan Buleleng.

\section{HASIL PENELITIAN}

Tabel. 1

Distribusi Frekuensi Usia

\begin{tabular}{lllllll}
\hline Variabel & $\mathrm{N}$ & Mean & Mix & Max & SD & $95 \%$ CI \\
\hline Usia & 39 & 4,41 & 4 & 5 & 0,498 & $4,25-4,57$ \\
\hline Sumber: Data Primer (2019) & & & &
\end{tabular}

Berdasarkan tabel 1 dapat disimpulkan bahwa usia termuda dari responden yaitu 4 tahun dan usia tertua yaitu 5 tahun.

Tabel. 2

Distribusi Frekuensi Jenis Kelamin

\begin{tabular}{ccc}
\hline Usia & Frekuensi (f) & Persentase (\%) \\
\hline Laki-laki & 17 & 43,6 \\
Perempuan & 22 & 56,4 \\
\hline Total & 39 & 100 \\
\hline Sumber: Data Primer $(2019)$ & &
\end{tabular}

Sumber: Data Primer (2019)

Berdasarkan tabel 2 distribusi frekuensi responden sebagian besar responden berjenis kelamin perempuan $56,4 \%$. 
Tabel. 3

Distribusi Frekuensi Perkembangan Motorik Halus Sebelum Diberikan Kegiatan Montase

\begin{tabular}{ccc}
\hline Perkembangan Motorik Halus & Frekuensi & Persentase (\%) \\
\hline Normal & 14 & 35,9 \\
Caution & 20 & 51,3 \\
Delayed & 5 & 12,8 \\
\hline Total & 39 & 100 \\
\hline
\end{tabular}

Sumber: Data Primer (2019)

Berdasarkan tabel 3 distribusi frekuensi dari perkembangan motorik halus tertinggi berada pada kategori caution dengan jumlah 20 orang anak $(51,3 \%)$ dan terendah berada pada kategori delayed dengan jumlah 5 orang anak $(12,8)$.

Tabel. 4

Analisis Perkembangan Motorik Halus

Sebelum Diberikan Kegiatan Montase

\begin{tabular}{llllllll}
\hline Variabel & N & Mean & Mix & Max & SD & Std. Error & $95 \%$ CI \\
\hline Pre Test & 39 & 43,44 & 14 & 70 & 18,393 & 2,945 & $37,47-49,40$ \\
\hline \multicolumn{2}{l}{ Sumber: Data Primer (2019) }
\end{tabular}

Berdasarkan tabel 4 rata-rata (mean) skor perkembangan motorik halus anak sebelum diberikan kegiatan montase adalah 43,44, standar deviation 18,393, standart error mean 2,945, dengan skor terendah 14 dan skor tertinggi 70, dan $95 \%$ confidence interval for mean 37,47-49,40.

Tabel. 5

Distribusi Frekuensi Perkembangan Motorik Halus Sesudah Diberikan Kegiatan Montase

\begin{tabular}{ccc}
\hline Perkembangan Motorik Halus & Frekuensi & Persentase $(\%)$ \\
\hline Advanced & 14 & 35,9 \\
Normal & 18 & 46,1 \\
Caution & 6 & 15,4 \\
Delayed & 1 & 2,6 \\
\hline Total & 39 & 100 \\
\hline
\end{tabular}

Sumber: Data Primer (2019)

Berdasarkan Tabel 5 distribusi frekuensi perkembangan motorik halus tertinggi berada pada kategori normal dengan jumlah 18 orang diberikan kegiatan montase. Motorik halus terendah berada pada kategori delayed dengan jumlah 1 orang anak $(2,6 \%)$.

Tabel. 6

Analisis Perkembangan Motorik Halus

Sebelum Diberikan Kegiatan Montase

\begin{tabular}{clllllll}
\hline Variabel & N & Mean & Min & Max & SD & Std. Error & $95 \%$ CI \\
\hline Post Test & 39 & 68,21 & 14 & 98 & 19,319 & 3,094 & $\begin{array}{l}61,94- \\
74,47\end{array}$ \\
\hline
\end{tabular}

Sumber: Data Primer (2019) 
Berdasarkan tabel 6 rata-rata (mean) skor perkembangan motorik halus anak sesudah diberikan kegiatan montase adalah 68,21, standar deviation 19,319, standart error mean 3,094, dengan skor terendah 14 dan skor tertinggi 98, dan 95\% confidence interval for mean 61,94-74,47.

Tabel. 7

Uji Normalitas Skewness

\begin{tabular}{llll}
\hline & Skeweness & Std. Error & Hasil Bagi \\
\hline Pre Test & 0,022 & 0,378 & 0,058 \\
Post Test & $-0,518$ & 0,378 & $-1,370$ \\
\hline
\end{tabular}

Berdasarkan tabel 7 hasil pembagian skewness dan standar error dari skor pre test dan post test berturut-turut adalah 0,058 dan $-1,370$ (nilai $\leq 2$ ), sehingga dapat disimpulkan bahwa data berdistribusi normal dan uji statistik yang digunakan adalah statistik parametrik dengan uji paired sample T-test.

Tabel. 8

Hasil Analisis Pre dan Post Test

\begin{tabular}{lllc}
\hline \multicolumn{1}{c}{ Variabel } & N & Mean & P. Value \\
\hline Pre Test & 39 & 43,44 & \multirow{2}{*}{0,000} \\
Post Test & 39 & 68,21 & \\
\hline
\end{tabular}

Hasil uji paired sample T-test menunjukkan hasil rata-rata (mean) perkembangan motorik halus sebelum diberikan intervensi kegiatan montase yaitu 43,44 dan setelah diberikan intervensi kegiatan montase meningkat menjadi 18,81. Penelitian ini membuktikan bahwa terdapat pengaruh kegiatan montase terhadap perkembangan motorik halus anak usia pra sekolah 4-5 Tahun.

\section{PEMBAHASAN}

\section{Karakteristik Responden}

Karakteristik usia di dapatkan bahwa rata-rata usia responden (mean) adalah 4,41 tahun. Usia yang paling muda adalah 4 tahun dan usia yang paling tua adalah 5 tahun. Berdasarkan hasil penelitian diatas menurut peneliti usia 4-5 tahun dianggap sebagai usia keemasan (the golden age) karena pada saat usia tersebut anak sedang mengalami pertumbuhan dan perkembangan yang sangat cepat baik secara fisik maupun psikis. Anak usia 4-5 tahun memperoleh pengalaman dari lingkungannya termasuk juga stimulasi yang diberikan oleh orang dewasa yang akan mempengaruhi kehidupan anak dimasa yang akan datang.

Pada usia 4-5 tahun anak akan memasuki periode yang disebut dengan preschool years, selama masa ini anak akan belajar untuk lebih mandiri dan memperhatikan dirinya. Mereka juga mengembangkan kesiapan untuk sekolah (seperti mengikuti perintah dan mengenal huruf) dan menghabiskan sebagian besar waktunya untuk bermain. Kecerdasan anak dilihat dari aktifnya anak melakukan sesuatu. Hal ini juga sejalan dengan penelitian yang dilakukan oleh Susilawati (2019) hasil penelitian ini menunjukkan penilaian kecerdasan anak usia dini dalam aspek bekerja sama, 
bersosialisasi dan menghargai temannya dalam bekerja dapat ditingkatkan dengan menggunakan metode pemberian tugas kelompok.

Karakteristik responden berdasarkan jenis kelamin sebagian besar responden berjenis kelamin perempuan dengan jumlah 22 orang $(56,4 \%)$ dan laki-laki dengan jumlah 17 orang $(43,6 \%)$. Dalam hal ini jenis kelamin seseorang tidak memiliki pengaruh terhadap perkembangan motorik halus pada anak. Pada penelitian ini lebih banyak responden berjenis kelamin perempuan karena kondisi demografi dari tempat penelitian yaitu di TK Saiwa Dharma Kelurahan Banyuning lebih banyak siswa perempuan dari pada siswa laki-laki. Hal ini sejalan dengan penelitian oleh Ni Luh Diah (2019) pada 22 anak usia 4-5 tahun dengan menggunakan DDST II. Hasil penelitian sebagian besar berjenis kelamin perempuan $82,4 \%$. Tidak ada perbedaan antara laki-laki dan perempuan. Perkembangan motorik halus dipengaruhi oleh banyaknya latihan yang dilakukan.

\section{Perkembangan Motorik Halus Sebelum Diberikan Kegiatan Montase}

Sebelum diberikan perlakuan Kegiatan Montase pada anak usia pra sekolah 4-5 tahun di TK Saiwa Dharma Kelurahan Banyuning, terlebih dahulu peneliti melakukan komunikasi pada anak untuk membina hubungan saling percaya antara anak dan peneliti. Setelah itu peneliti melakukan penelitian terhadap perkembangan motorik halus dengan menggunakan lembar observasi yang memiliki 7 tugas dengan skor terendah yaitu 14 dan skor tertinggi yaitu 98. Pengukuran dilakukan 1 kali sebelum ( pre test) diberikan kegiatan montase dan sesudah (post test) diberikan kegiatan montase.

Salah satu upaya yang dapat dilakukan untuk meningkatkan perkembangan motorik halus anak melalui metode bermain seperti kegiatan montase. Karya montase dihasilkan dari menyatukan dan menggabungkan gambar dari berbagai sumber yang berbeda-beda dengan susunan tertentu yang ditempelkan pada sebuah bidang datar. Dalam kegiatan montase terdapat unsur menggunting dan menempel yang menuntut gerakan otot jari-jari tangan koordinasi pada mata dan tangan serta daya imajinatif dalam menghasilkan sebuah karya yang dapat menstimulasi perkembangan motorik halus.

Perkembangan motorik halus merupakan koordinasi halus pada otot-otot kecil yang memainkan suatu peran utama. Penelitian yang dilakukan oleh Rakimahwati et al, (2018) dengan jenis penelitian quasi eksperimen terhadap 24 anak usia 5-6 tahun. Karigami terbukti dapat meningkatkan kemampuan motorik halus anak usia dini.

Hasil penelitian menunjukkan bahwa 39 orang responden yang berusia 4-5 tahun rata-rata (mean) nilai perkembangan motorik halus pada anak sebelum diberikan intervensi kegiatan montase adalah 43,44 (95\% CI: 37,47-49,40), standar deviation 18,393, standart error mean 2,945, dengan skor terendah adalah 14 dan skor tertinggi adalah 70. Dari data tersebut didapatkan hasil pengukuran perkembangan yang berbedabeda. Bagi peneliti perkembangan fisik merupakan hal yang menjadi dasar bagi kemajuan perkembangan berikutnya. Ketika fisik berkembang dengan baik memungkinkan anak untuk dapat lebih baik mengembangkan keterampilan fisiknya. Perkembangan fisik anak ditandai dengan berkembangnya perkembangan motorik baik itu motorik halus maupun motorik kasar.

Motorik halus adalah gerakan yang menggunakan otot-otot halus atau sebagian tubuh tertentu dipengaruhi oleh kesempatan untuk belajar atau berlatih contohnya kemampuan untuk memindahkan benda dari tangan, mencoret-coret, menyusun balok, menggunting, menulis, dan lain sebagainya Namun pada saat melakukan penelitian di 
TK Saiwa Dharma Kelurahan Banyuning terdapat 25 orang anak yang mengalami perkembangan motorik halus kurang, perbedaan ini dipengaruhi oleh pembawaan dan stimulasi yang didapatkannya dimana lingkungan (orang tua) mempunyai pengaruh yang sangat besar dalam kecerdasan motorik halus, faktor tersebut mampu meningkatkan ataupun menurunkan taraf kecerdasannya terutama pada masa-masa awal kehidupannya.

Hasil penelitian ini sejalan dengan penelitian yang dilakukan oleh Diana (2019) penelitian pada 35 orang tua yang mempunyai anak usia 3-4 tahun dengan menggunakan lembar kuesioner pola asuh orang tuan dan penilaian DDST untuk anak. Hasil penelitian sebagian besar pola asuh orang tua dominan demokratif dengan perkembangan motorik halus advance 54,3\%. Perkembangn motorik sangat diperlukan peran orang tua dalam mengasuh dan mendidik anaknya. Pengetahuan yang dimiliki orang tua sangat baik untuk memberiakn stimulus pada anaknya.

\section{Perkembangan Motorik Halus Setelah Diberikan Kegiatan Montase}

Setelah diberikan perlakuan kegiatan montase pada anak usia pra sekolah 4-5 tahun selama 3 minggu dalam 6 kali pertemuan, hasil penelitian ini menunjukkan bahwa Rata-rata (mean) nilai perkembangan motorik halus pada anak sesudah diberikan intervensi kegiatan montase adalah 68,21 (95\% CI: 61,94-74,47), standar deviation 19,319, standart error mean 3,094, dengan skor terendah adalah 14 dan skor tertinggi adalah 98, dan dari estimasi interval dapat disimpulkan bahwa 95\% rata-rata tingkat perkembangan motorik halus pada anak usia 4-5 tahun di TK Saiwa Dharma Kelurahan Banyuning adalah 61,94-74,47.

Penelitian oleh Irma (2018) pada 14 anak usia 4-5 tahun dengan metode observasi. Penggunaan alat peraga dapat menstimulasi anak menjadi antusias, senang dan tidak mudah menyerah. Metode demonstrasi pada kegiatan $3 \mathrm{M}$ dapat meningkatkan perkembangan motorik halus pada anak.

Kegiatan montase ini dapat merangsang perkembangan motorik halus anak usia 45 tahun karena pada kegiatan montase terdapat unsur menggunting dan menempel yang dapat menuntut gerakan otot jari-jari tangan koordinasi pada mata serta daya konsentrasi dan imajinatif dalam menghasilkan sebuah karya, sehingga dapat menstimulasi perkembangan motorik halus. Hal ini sejalan dengan penelitian yang dilakukan Cahyaningrum (2019) dengan sampel dalam penelitian ini 15 anak dengan model penelitian McTaggart dengan tehnik pengumpulan data menggunakan lembar observasi bentuk checklist. Kegiatan montase dapat meningkatkan keretampilan motorik halus $81,52 \%$.

\section{Pengaruh Kegiatan Montase terhadap Perkembangan Motorik Halus Anak Usia Pra Sekolah 4-5 Tahun}

Hasil uji statistik menggunakan uji paired sample T-test didapatkan bahwa $\rho$-value $0,000(\rho<0,005)$. Hasil ini menandakan bahwa $\mathrm{H}_{0}$ dalam penelitian ini ditolak dan $\mathrm{H}_{\mathrm{a}}$ diterima yang berarti ada pengaruh kegiatan montase terhadap perkembangan motorik halus anak usia pra sekolah 4-5 tahun, untuk mengetahui pengaruh kegiatan montase terhadap perkembangan motorik halus anak usia pra sekolah 4-5 tahun di TK Saiwa Dharma Kelurahan Banyuning, dengan cara membandingkan hasil rata-rata (mean) skor perkembangan motorik sebelum dan sesudah intervensi kegiatan montase. 
Penelitian yang dilakukan oleh Padila et al, (2019) selama 1 bulan pada anak usia toddler. Penelitian ini menggunakan metode penelitian kuantitatif dengan rancangan quasy eksperimen, pre-post test equivalent without control group design. Hasil analisis bivariat dalam penelitian ini menunjukkan bahwa terdapat peningkatan skor tahap perkembangan pada kelompok DDST dan pada kelompok SDIDTK dengan masingmasing ( $\mathrm{t}$ value $=-3,096, \mathrm{p}$ value $=0,013)$ dan $(\mathrm{t}$ value $=-2,703, \mathrm{p}$ value $=0,024)$ sehingga terdapat pengaruh yang signifikan antara skor tahap perkembangan pada kelompok DDST dan pada kelompok SDIDTK sebelum dan setelah dilakukan intervensi. Metode DDST digunakan untuk menilai perkembangan anak sedangkan SDIDTK untuk menilai pertumbuhan dan perkembangan anak. Anak usia pra sekolah merupakan anak yang berusia antara 0-6 tahun.

Hasil rata-rata (mean) dari perkembangan motorik halus sebelum diberikan intervensi kegiatan montase adalah 43,44 dan sesudah diberikan intervensi kegiatan montase menjadi 68,21. Penelitian ini membuktikan adanya pengaruh kegiatan montase terhadap perkembangan motorik halus anak usia pra sekolah 4-5 tahun di TK Saiwa Dharma Kelurahan Banyuning.

Kegiatan montase merupakan metode pembelajaran yang menuntut koordinasi pada mata dan jari-jari tangan, sehingga akan melatih konsentrasi anak selain itu kegiatan ini juga dapat mengenalkan warna, bentuk, dan ukuran. Memiliki bermacammacam kombinasi antara lain binatang, tumbuhan, kotak, dan segitiga. Perkembangan motorik halus merupakan koordinasi halus pada otot-otot kecil yang memainkan suatu peran utama. Suatu keterampilan menulis huruf "a" merupakan serangkaian beratusratus koordinasi dari saraf otot. Pergerakan terampil adalah proses yang sangat kompleks. Variasi pekembangan motorik halus mencerminkan kemauan dan kesempatan individu untuk belajar. Anak yang jarang menggunakan krayon akan mengalami keterlambatan pada perkembangan untuk memegang pensil. Perkembangan motorik halus pertama yang dengan mudah dapat dikenali dan merupakan perkembangan yang sangat penting adalah kemampuan mengepalkan tangan.

Pernyataan ini didukung oleh penelitian yang dilakukan oleh Titi (2018) yang dilakukan pada 10 anak usia 5-7 tahun menggunakan metode action research. Desain penelitian dengan model Kemmis dan Taggart yaitu dikakukan dalam tiga siklus dan tiga tindakan pada setiap siklusnya. Kegiatan montase dapat meningkatkan kreativitas anak dan memberikan kebebasan anak untuk bereksplorasi, bebas menggunting, membuat dan memilih sendiri gambar yang menarik untuk disusun sesuai keinginan.

\section{SIMPULAN}

Karakteristik berdasarkan usia yaitu dari 39 orang responden memiliki usia termuda 4 tahun dan usia tertua 5 tahun. Karakteristik berdasarkan jenis kelamin sebagian besar responden berjenis kelamin perempuan. Setelah diberikan kegiatan montase perkembangan motorik halus meningkat. Kegiatan montase merupakan penggabungan gambar-gambar yang dihasilkan dari percampuran unsur dari beberapa sumber.

Karya montase dihasilkan dari menyatukan atau menggabungkan gambar-gambar dari sumber yang berbeda-beda dengan susunan tertentu yang ditempelkan pada sebuah bidang datar. Dalam kegiatan montase terdapat unsur menggunting dan menempel yang menuntut gerakan otot jari-jari tangan koordinasi mata dan tangan serta daya imajinatif dalam menghasilkan sebuah karya yang menstimulasi perkembangan motorik halus. Motorik halus merupakan gerakan terbatas dari bagian yang meliputi otot-otot kecil 
terutama gerakan dibagian jari-jari tangan contohnya yaitu menulis, menggambar, dan memegang sesuatu.

\section{SARAN \\ Bagi Pelayanan}

Kepada masyarakat khususnya orang tua agar lebih mendampingi anak saat belajar agar anak mudah mengerti. Pola asuh orang tua sangat penting untuk peningkatan kemampuan motorik halus halus pada anak. Kepada sekolah bisa menerapkan kegiatan montase untuk perkembangan motoric halus pada anak.

\section{Bagi Keilmuan}

Penelitian ini dapat dimasukan dalam sub bab pada mata kuliah keperawatan anak sebagai penatalaksanaan tumbuh kembangang anak. Bagi peserta didik dapat menambah wawasan dan pengetahuan tentang kegiatan montase dapat meningkatkan perkembangan motorik halus pada anak.

\section{Bagi Peneliti Selanjutya}

Memberikan rekomendasi pada pengembangan riset keperawatan dengan penelitian lanjutan dengan menambahkan variabel seperti pola asuh, lingkungan yang dapat mempengaruhi perkembangan motorik pada anak. Menggunakan sampel yang besar dengan desain penelitian yang berbeda.

\section{DAFTAR PUSTAKA}

Alif, M. N. (2019). Identifikasi Keterampilan Motorik Halus Anak. Journal of Early Childhood Care \& Education, 2(1), 14-20

Cahyaningrum, B. A. (2019). Meningkatkan Keterampilan Motorik Halus melalui Kegiatan Montase di Kelompok B3 TK Kencana Putra Pengasih Kulon Progo

Diana, W. (2019). Hubungan Pola Asuh Orangtua dengan Perkembangan Motorik Halus Anak Usia Prasekolah. (di PAUD Harapan Bunda Surabaya). J-Hestech (Journal Of Health Educational Science And Technology), 2(1), 51-60. https://doi.org/10.25139/htc.v2i1.1660

Intan. N. W I. N. (2018). Pengaruh Kegiatan Mozaik terhadap Kemampuan Motorik Halus Anak Usia 4-6 Tahun. "Ceria" Jurnal Program Studi Pendidikan Anak Usia Dini, 7(2), 12-25

Irma, O. A. S., \& Aziz, A. (2018). Meningkatkan Perkembangan Motorik Halus Anak melalui Kegiatan 3M (Mewarnai, Menggunting, Menempel) dengan Metode Demonstrasi. Jurnal Ilmiah Tumbuh Kembang Anak Usia Dini, 3(3), 191-204

Maghfuroh, L. (2018). Metode Bermain Puzzle Berpengaruh pada Perkembangan Motorik Halus Anak Usia Prasekolah. Jurnal Endurance, 3(1), 55-60

Dewi, N. L. D. (2019). Analisis Faktor yang Mempengaruhi Perkembangan Motorik Halus pada Anak Usia Prasekolah di TK Ra Diponegoro Desa Ngajum Kabupaten Malang. Mesencephalon Jurnal Kesehatan, 5(2), 133-143

Padila, P., Andari, F. N., \& Andri, J. (2019). Hasil Skrining Perkembangan Anak Usia Toddler antara DDST dengan SDIDTK. Jurnal Keperawatan Silampari, 3(1), 244-256. https://doi.org/10.31539/jks.v3i1.809

Rakimahwati, R., Lestari, N. A., \& Hartati, S. (2018). Pengaruh Kirigami terhadap Kemampuan Motorik Halus Anak di Taman Kanak-Kanak. Jurnal Obsesi : Jurnal Pendidikan Anak Usia Dini, 2(1), 98. https://doi.org/10.31004/obsesi.v2i1.13

Susilawati, S. (2019). Peningkatan Kecerdasan Interpersonal. 1-9 
Titi, R. M. H. (2018). Optimalisasi Kreativitas Anak melalui Aktifivitas Montase pada Usia Taman Kanak-Kanak. Jurnal iImiah Indonesia, 3(3), 161-168 